\title{
Forestry on fans: a problem analysis ${ }^{1}$
}

\author{
by David Wilford ${ }^{2}$, Matt Sakals ${ }^{3}$ and John Innes ${ }^{4}$
}

Forested fans are often crossed by roads and their high-volume stands are attractive for harvesting. Gentle slopes of fans belie the fact that hydrogeomorphic hazards can be present. Fans can be the run out zones for debris flows and they can be subject to floods and debris floods. This study assessed the effect of natural hydrogeomorphic processes on forest practices that were undertaken on 55 fans in west central British Columbia. Forest practices aggravated these processes on 41 (74\%) fans, leading to increased erosion and destabilization of fan surfaces and stream channels. Identification of hydrogeomorphic hazards is needed to avoid the adverse effects of forestry practices on fans.

Keywords: forested fans, forestry on fans, hydrogeomorphic processes, forest practices on fans, forest practices

Les cônes d'alluvion boisés sont souvent parcourus de routes et leurs peuplements à fort volume de bois sont attrayants pour l'exploitation forestière. Les pentes douces des cônes d'alluvion cachent le fait que des accidents hydrogéomorphologiques puissent survenir. Les cônes d'alluvion peuvent être des zones de débordement pour les écoulements de débris et peuvent subir des inondations et déversements de débris. Cette étude a évalué l'effet des processus hydrogéomorphologiques naturels sur les pratiques forestières qui ont été entreprises sur 55 cônes d'alluvion dans le centre-ouest de la Colombie-Britannique. Les pratiques forestières ont aggravé ces processus sur $41(74 \%)$ des cônes d'alluvion, menant à une érosion accrue et une déstabilisation de la surface des cônes d'alluvion et des canaux des cours d'eau. L'identification des risques hydrogéomorphologiques est requise afin d'éviter les effets négatifs des pratiques forestières sur les cônes d'alluvion.

Mots-clés : cônes d'alluvion boisés, foresterie sur les cônes d'alluvion, processus hydrogéomorphologique, pratiques forestières sur les cônes d'alluvion

\section{Introduction}

Prescriptions for forest practices in British Columbia are currently based on a wide range of ecological and physical criteria. For example, the biogeoclimatic classification is applied to ensure that appropriate silvicultural treatments are site-based (Mah et al. 1996). Conventional road construction and harvesting prescriptions are modified where landslide prone terrain is identified (Anon.

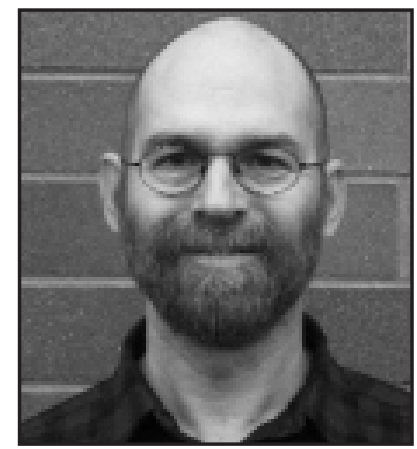

David Wilford 1999). Special riparian prescriptions are developed where fish habitat is present (Anon 1995a). However, no special recognition is given to forest practices on alluvial and colluvial fans. This project was undertaken at the request of operational forestry staff who were concerned that the lack of hazard recognition and the application of conventional forestry practices on fans were leading to unnecessary financial and environmental impacts. This study assesses the interaction between contemporary, natural hydrogeomorphic processes and a range of forestry practices undertaken on fans in west central British Columbia.

1Paper presented at "Mountain Forests: Conservation and Management," IUFRO Silviculture Conference, Vernon, British Columbia, Canada, July 28-August $1,2002$.

${ }^{2}$ BC Ministry of Forests, Bag 5000, Smithers, BC, Canada, V0J 2N0. E-mail: dave.wilford@gems3.gov.bc.ca

${ }^{3}$ BC Ministry of Forests, Bag 5000, Smithers, BC, Canada, V0J 2NO. E-mail: matt.sakals@gems7.gov.bc.ca

${ }^{4}$ UBC Faculty of Forestry, 2424 Main Mall, Vancouver, BC, Canada, V6T 1Z4.E-mail: innes@interchange.ubc.ca

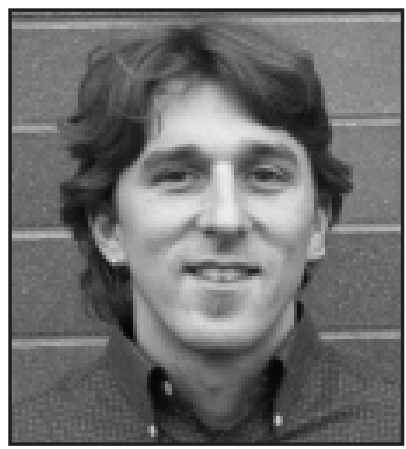

Matt Sakals

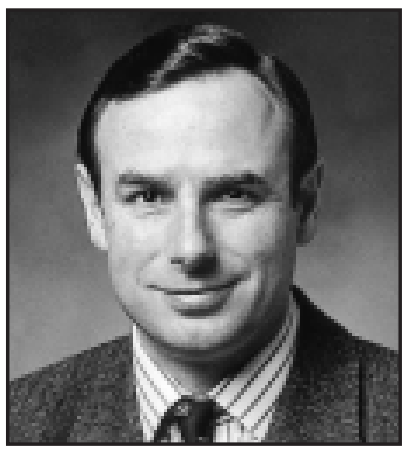

John Innes
A fan is a cone-shaped deposit of sediment formed where a stream emerges from the confines of a mountain (Bull 1977). Sediment originates in a source-area watershed and is transported to a fan by hydrogeomorphic processes (floods, debris floods and debris flows). In some cases, the deposition of sediment is linked to paraglacial episodes unrelated to modern conditions (Ryder 1971a, 1971b; Church and Ryder 1972; Ritter et al. 1993). In other situations, it is apparent that fans are actively growing (Beaty 1970). In mountainous terrain, it is not uncommon for contemporary hydrogeomorphic processes to be actively influencing at least a portion of the fan surface (Jakob and Jordan 2001). The zone of activity is characteristically, but not limited to, the stream channel area.

Hydrogeomorphic hazards on fans have been described (VanDine 1985, Kellerhals and Church 1990) and studies of specific fans have led to hazard zonation (Thurber Consultants 1983). However, there is no body of research regarding forest practices on fans and there is not a hazard classification for forestry planning on fans. Thus, hydrogeomorphic hazards on fans are not identified in the course of forest development planning in 


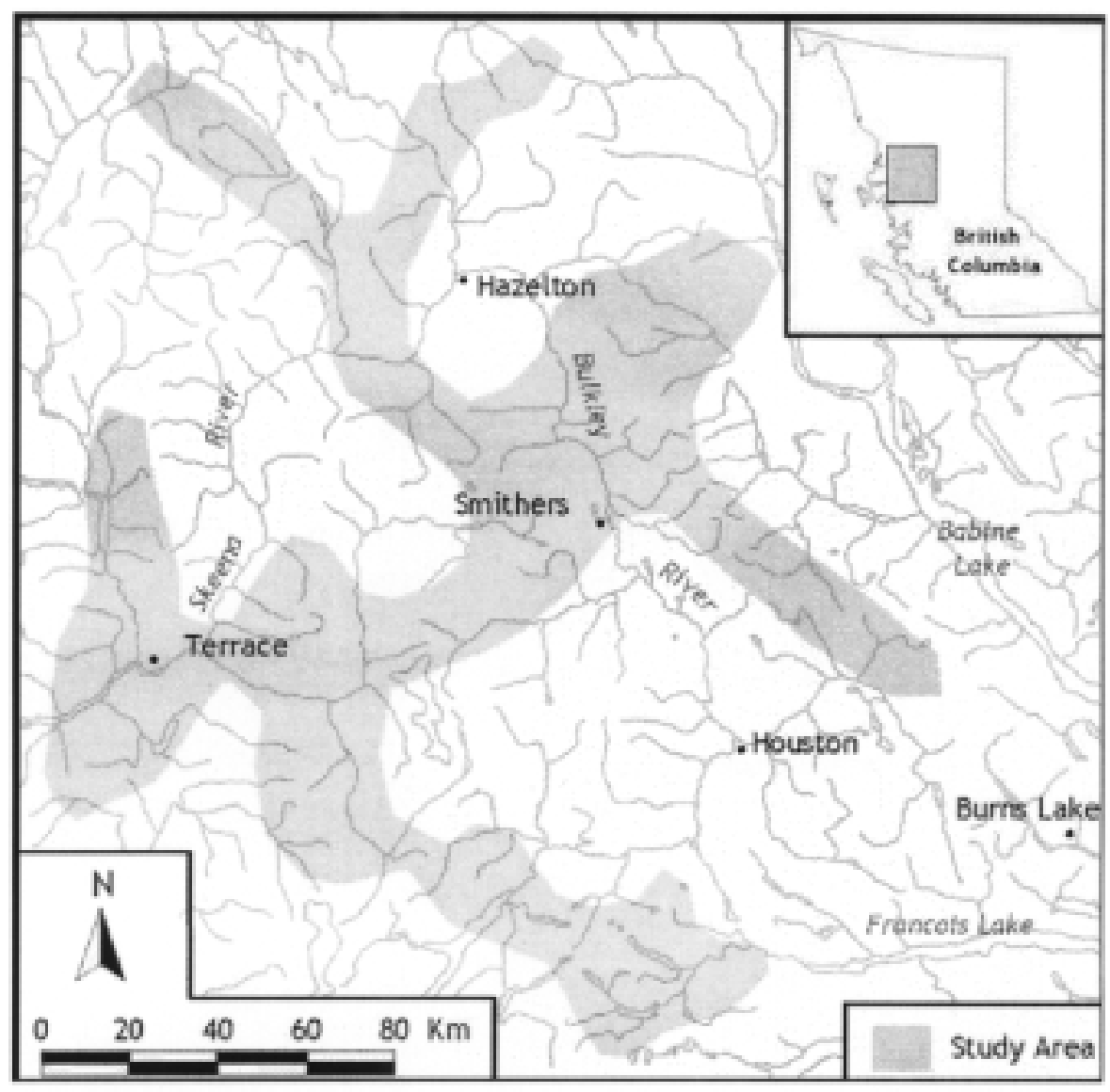

Fig. 1. Location map of the study area.

$\mathrm{BC}$. The current situation is that drainage structures on fans are built to accommodate 50- or 100-year flood events (Anon. 1995b), not hydrogeomorphic events, and the decision to retain riparian forests is based on the presence or absence of fish (Anon 1995b). The descriptive assessment presented in this paper clearly demonstrates that conventional forest practices should recognize hydrogeomorphic hazards on fans.

\section{Study Area}

The study area is in west-central British Columbia and study fans lie across a broad geographic area, between $53^{\circ} 46^{\prime}$ and $55^{\circ} 43^{\prime}$ north latitude and $126^{\circ}$ and $129^{\circ} 10^{\prime}$ west longitude (Fig. 1). The western fans are within the Coastal Western Hemlock (CWH) Biogeoclimatic Zone and their watersheds have Mountain Hemlock (MH) and Alpine Tundra (AT) Zones at higher elevations (Banner et al. 1993). The central fans are within the Interior Cedar Hemlock (ICH) Biogeoclimatic Zone and their watersheds have Englemann Spruce - Subalpine Fir (ESSF) and AT Zones at higher elevations. The eastern fans are within the Sub-Boreal Spruce Biogeoclimatic Zone (SBS) and their watersheds have ESSF and AT Zones at higher elevations. Some of the eastern fans are totally within the ESSF Zone.

The study area lies within the Western and Interior Systems of the Canadian Cordillera (Holland 1964). The Western System is represented by the Kitmat Ranges of the Coast Mountains. They are granitic mountains, characteristically round-topped and domed because they were overridden by glacial ice. The Interior System includes the Skeena Mountains, Nass Basin, Hazelton Mountains and the Nechako Plateau. This system is underlain chiefly by volcanic and sedimentary rocks and overall is less rocky and rugged than the Western System.

The study area was glaciated during the Fraser glaciation with ice retreat completed between 10700 and 9300 years BP (Alley and Young 1978, Clague 1984). The legacy of the glaciation is extensive morainal and glacial-fluvial deposits that dominate the landscape, masking much of the underlying bedrock (Runka 1972). Fans are a post-glacial feature in the study area reflecting paraglacial (Ryder 1971a, 1971b; Church and Ryder 1972) and contemporary conditions.

A series of stream gauging stations are operated by the Water Survey of Canada in the study area. Most gauged watersheds are very large compared to the study watersheds, making unit runoff calculations and even event dating problematic. However, the hydrometric data are useful in describing the principal runoff regimes. Characteristically the western and central portions of the study area experience biannual peakflows. Spring snowmelt provides the highest volume of runoff, and in some years the highest peakflows. Fall rain or rain-onsnow events can produce significant peakflows as well as erosion events (debris avalanches and debris flows) (Septer and Schwab 1995). The same biannual peakflows occur in the eastern portion of the study area, although in general the spring snowmelt peaks are significantly larger than the fall peakflows.

Floods, debris floods and debris flows occur throughout the study area (Septer and Schwab 1995). Debris flows are relatively common in the smaller watersheds $\left(<5 \mathrm{~km}^{2}\right)$ in the western portion of the study area but also occur in the eastern portion. Debris floods occur throughout the study area in 

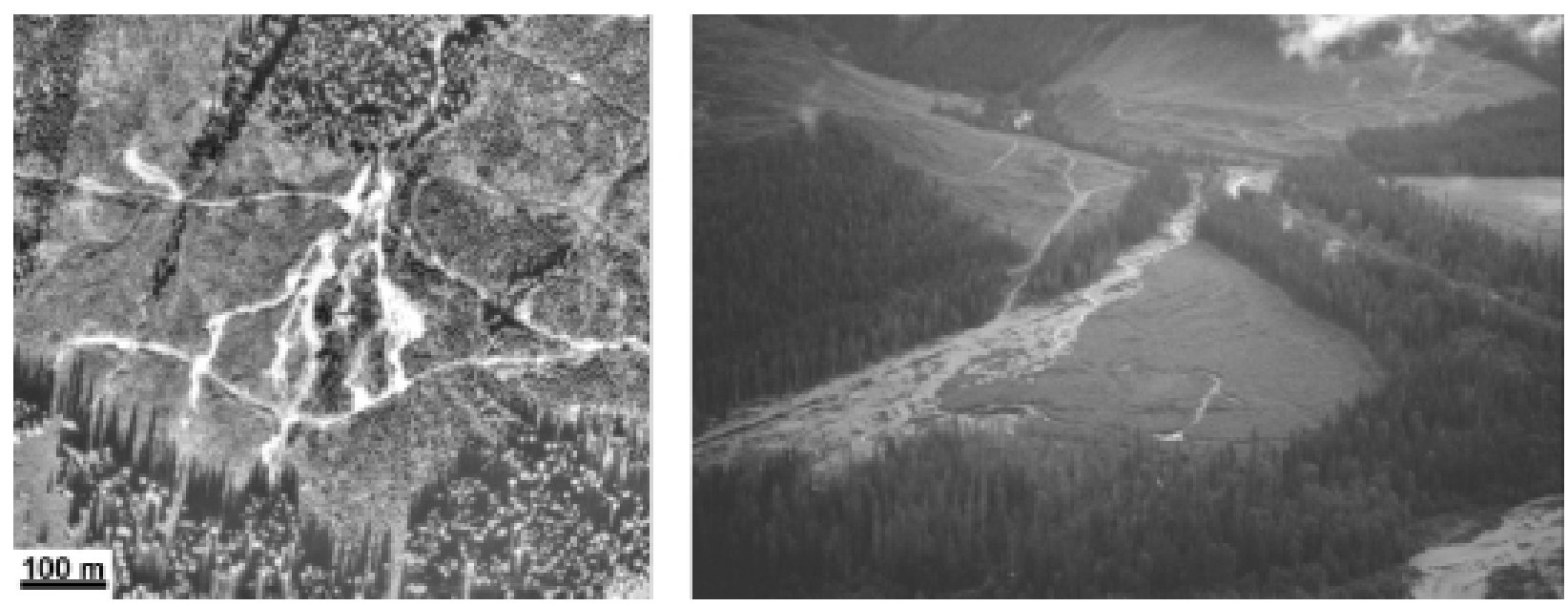

Fig. 2. Examples of major impacts on fans. Broadcasting of sediments and diversion of stream channels.

watersheds less than $30 \mathrm{~km}^{2}$. Floods occur as the dominant hydrogeomorphic process in the larger watersheds of the study (> $20 \mathrm{~km}^{2}$ ) but also occur on an annual basis in debris flood and debris flow watersheds.

\section{Methods}

Study fans were selected based on four criteria: reasonable access, availability of historic information regarding forestry activities, forestry being the only land use activity and no or very limited forestry activity in the contributing watershed, and providing a reasonable cross-section of fans within the study area (forestry practices and hydrogeomorphic processes). The selection process was biased, but not exclusively, toward fans with forest management problems arising from hydrogeomorphic events. Thus, the study provides details on the factors surrounding forestry practices that are problematic rather than on a representative sample of fans with forestry practices.

The nature of forestry problems related to hydrogeomorphic processes, or lack of problems, was established for each fan prior to fieldwork through discussions with staff from forest licensees and government agencies. An assessment was undertaken on each fan to determine if a forestry practice exacerbated the effects of a hydrogeomorphic event. Five categories of forestry practices were established: inadequate drainage structures or channel excavation, roads and ditches, riparian clearcut logging, large woody debris (LWD) removal from the stream, and mass wasting related to forest practices in the contributing watershed. It was necessary to establish that the resulting erosion or sediment deposition would not have occurred if the forestry practice had not taken place. In most cases, this was obvious. For example, "inadequate drainage structure" describes the situation where a structure did not have the ability to convey the water, sediment and woody debris from a hydrogeomorphic event, resulting in a diversion. Field descriptions included road profiles (using a Suunto and metre tape), drainage structure dimensions and condition, presence or absence of riparian forests (clearcut versus natural forest), hydrogeomorphic processes (VanDine 1985, Smith 1986, Pierson and Costa 1987, Wells and Harvey 1987, Costa 1988), evidence of erosion or sediment deposition (in channels and on roads and fan surfaces) and impacts.
Impacts were classified as major (P1) if damage was significant: major drainage structures required replacement, erosion of at least $100 \mathrm{~m}$ of road, streams impacted to the point where there was no or very poor fish habitat (Johnston and Slaney 1996), or more than 1 ha of plantations or forest stands were buried in sediments or eroded (Fig. 2). Impacts were classified as limited (P2) if there was localized erosion of roads and limited impacts to drainage structures, plantations, forest sites and fish habitat. Attempts were made to determine the financial value of problems, particularly in restoring access across fans. However, very few situations were found where costs were available because specific records for individual fans were not available.

The data were used to provide a descriptive assessment of the interaction between hydrogeomorphic processes and forestry practices on fans. For several reasons, this approach was used rather than a statistical comparison of fans with forestry activities versus fans with no forestry activities (e.g., extent of sediment splays). Some practices had very few data points, precluding a complete statistical comparison. Undertaking detailed measurements of features such as sediment splays from hydrogeomorphic events on natural versus logged and roaded fans is very time-consuming and would not address the basic question, namely which practices are aggravating natural hydrogeomorphic events and why? The descriptive assessment was thus a direct method to address the question and the overall sample size of fans (55) was considered adequate to provide a sufficiently valid database.

\section{Results and Discussion}

Of the many fans fitting the selection criteria, 55 were studied. They had a range of forestry activities from single road crossings to complete clearcutting. The dates of forestry activities ranged from recent to 50 years old, although the majority of fans had forestry activities in the past 20 years. A summary of results is presented in Table 1 .

All study fans had drainage structures, although two structures were located at the fan apex with the road located on the adjacent hill slopes. Inadequate drainage structures and channel excavations for the installation and maintenance of drainage structures exacerbated hydrogeomorphic processes on 30 of the 
Table 1. Forest practices and impacted features associated with hydrogeomorphic events. Percentages are presented by the total in each category

\begin{tabular}{|c|c|c|c|c|}
\hline & \multirow[b]{2}{*}{ Total in each category } & \multicolumn{3}{|c|}{ Class of Impact } \\
\hline & & P1 (major) & P2 (limited) & $\mathbf{P 1}+\mathbf{P 2}$ \\
\hline Total fans with forestry activities and & 55 & 27 & 14 & 41 \\
\hline total impacted fans by impact class & $100 \%$ & $49.1 \%$ & $25.4 \%$ & $74.5 \%$ \\
\hline \multicolumn{5}{|l|}{ Associated forestry practice } \\
\hline Drainage structure / Channel excavation & $55(100 \%)$ & $23(42 \%)$ & $7(13 \%)$ & $30(54 \%)$ \\
\hline Roads / Ditches & $53(100 \%)$ & $18(34 \%)$ & $6(11 \%)$ & $24(45 \%)$ \\
\hline Riparian logging & $24(100 \%)$ & $16(67 \%)$ & $7(29 \%)$ & $23(96 \%)$ \\
\hline LWD removal or burned & $4(100 \%)$ & $3(75 \%)$ & $1(25 \%)$ & $4(100 \%)$ \\
\hline Mass wasting related to forestry activities & $3(100 \%)$ & $1(33 \%)$ & $0(0 \%)$ & $1(33 \%)$ \\
\hline \multicolumn{5}{|l|}{ Impacted features } \\
\hline Roads & $53(100 \%)$ & $22(42 \%)$ & $10(19 \%)$ & $32(60 \%)$ \\
\hline Plantations/forest sites & $37(100 \%)$ & $22(59 \%)$ & $6(16 \%)$ & $28(76 \%)$ \\
\hline Drainage structures & $55(100 \%)$ & $19(34 \%)$ & $4(7 \%)$ & $23(42 \%)$ \\
\hline Fish habitat & $26(100 \%)$ & $14(54 \%)$ & $1(4 \%)$ & $15(58 \%)$ \\
\hline
\end{tabular}

55 study fans. The principle reason for the exacerbation was that structures were too small to pass water, debris and sediment associated with events. The most common result was a channel avulsion (Allen 1965) with the stream creating a new channel, either across the fan surface or down a road. This situation was the result of structures being built to pass the water flow of 50- to 100-year flood events. Debris floods can have a peak discharge of up to twice that of a flood event (Costa 1984). Debris flows can have a peak discharge of five to 40 times relative to a flood event (VanDine 1985). Only one case was found where a structure was designed to allow an event to pass over it (the road dropped to the crossing and the approaches were protected with riprap). It was apparent the hydrogeomorphic events affecting study fans are not rare events, but rather occur at least once during the period of normal forestry activities (i.e., 10 to 50 years). This situation has been identified in other mountainous areas (Innes 1985, Jakob and Jordan 2001). It is apparent that drainage structures on fans should be built with consideration of hydrogeomorphic events.

Roads and ditches increased the impacts from natural hydrogeomorphic events on 24 (45\%) of the 53 study fans with roads. The leading cause in all cases was roads that had a climbing grade to stream crossings (Table 2). Forest roads generally climb as they follow mountainous valleys, and as a result roads commonly climb as they cross fans. When drainage structures failed, water and sediment were channelled down roads, leading to erosion, the creation of new channels and the broadcasting of sediment (Table 3). Not all climbing roads led to problems (Table 4). The key factor in 10 (67\%) of the 13 cases where climbing roads did not cause impacts was the presence of adequate drainage structures. Other practices that prevented problems developing were the use of rolling grades at old stream channels that allowed water and debris to cross the road, locating a road across the lower portion of a fan, regular maintenance of drainage structures, effective deactivation, and narrow, outsloped roads with no ditches.

Clearcutting of riparian forests was observed on 24 study fans and 23 had some degree of impact. The impacts consisted of damage to plantations from broadcast sediment, channel widening and stream avulsions. While some of the logging predates the BC Forest Practices Code riparian guidelines (Anon. 1995a), the requirement for riparian reserves and management zones is based on the presence or absence of fish. Since only some study fans had streams with fish, it is likely that reserves would not have been left even under the current guidelines. As
Table 2. Summary of roads that climb to streams in at least one direction

\begin{tabular}{lccc}
\hline Impact Class & $\begin{array}{c}\text { Number of fans with } \\
\text { roads that climb } \\
\text { to the stream }\end{array}$ & $\begin{array}{c}\text { Road } \\
\text { associated } \\
\text { with impacts }\end{array}$ & $\begin{array}{c}\text { Road was } \\
\text { impacted }\end{array}$ \\
\hline P1 & 22 & 18 & 20 \\
P2 & 11 & 6 & 9 \\
Nil & 6 & - & - \\
Total & 39 & 24 & 29 \\
\hline
\end{tabular}

Table 3. Details of cases where climbing roads were associated with P1 and $\mathbf{P 2}$ impacts

\begin{tabular}{lcc}
\hline Details & $\begin{array}{c}\text { Number } \\
\text { of Cases }\end{array}$ & $\begin{array}{c}\text { \% of } \\
\text { Total (24) }\end{array}$ \\
\hline Inadequate drainage structure on main stream & 20 & $83 \%$ \\
Inadequate ditch blocks/inadequate cross drains & 18 & $75 \%$ \\
Road became stream channel & 17 & $71 \%$ \\
Ditchline interception or channelling flow & 14 & $58 \%$ \\
Road not deactivated promptly or adequately & 8 & $33 \%$ \\
Streambanks breached & 3 & $12 \%$ \\
\hline
\end{tabular}

\begin{tabular}{lcc}
\hline \multicolumn{3}{l}{ Table 4. Details of cases where climbing roads did not cause impacts. } \\
\hline Details & $\begin{array}{c}\text { Number } \\
\text { of Cases }\end{array}$ & $\begin{array}{c}\text { \% of } \\
\text { Total (15) }\end{array}$ \\
\hline $\begin{array}{l}\text { Adequate drainage structure or effective } \\
\quad \text { back-up structure }\end{array}$ & 10 & $67 \%$ \\
Rolling grade in road & 3 & $20 \%$ \\
Road crosses on lower fan & 3 & $20 \%$ \\
Regular maintenance of drainage structures & 3 & $20 \%$ \\
Effective deactivation & 2 & $13 \%$ \\
No ditchline and outsloped road & 2 & $13 \%$ \\
\hline
\end{tabular}

no direct streambank damage was observed, the impacts were attributed to tree and large woody debris removal that reduced the sediment storage capability of the riparian zone and reduced the surface roughness for broadcast flows.

Riparian zones provide a range of biological and physical functions, including nutrient inputs, bank stabilization, large woody debris inputs, shade, and deposition zones for sediment from upland sources (Beschta et al. 1987, Bisson et al. 1987, Bjornn and Reiser 1991, Murphy and Meehan 1991). A role that has been inadequately described in the literature is the importance of riparian forests with regards to hydrogeomorphic processes. This role appears to be critical on forested fans (Wilford et al 2002). 
Removal of large woody debris (LWD) from streams or reduction of LWD volume through prescribed burning occurred on four study fans. All experienced impacts due to the mobilization of bedload (i.e., loss of sediment storage) and reduced fish habitat complexity.

Mass wasting due to forest practices was rare due to the selection criteria of limited forestry activities in watersheds. Three study watersheds had landslides related to forest practices, and only one of these was associated with impacts on the fan. The landslide materials augmented the natural sediment and debris load, contributing to a channel avulsion.

While forest practices can exacerbate hydrogeomorphic events, they can also be impacted by the events. Roads were eroded on 32 study fans, with major reconstruction or relocation required on 22 fans. Drainage structures were damaged on 32 fans and reconstruction required on 19 fans. Plantations and forest sites were impacted on $28(51 \%)$ of the study fans, with major impacts on 22 fans. Fish habitat was impacted on 15 of the 26 fans with fisheries values, with nearly all the instances being major. None of the impacted forest sites or fish habitat observed on the study fans had been restored.

As noted previously, this study was not intended to present information from a representative sample of fans. However, it is likely that the sample is representative given that forestry practices are rarely modified to account for hydrogeomorphic processes. Observations of fans with forestry activity in other geographic areas of $\mathrm{BC}$ suggest that the results found in the study area are not unique.

\section{Conclusions}

This study summarizes the interaction between hydrogeomorphic processes and forest practices on 55 fans in west central British Columbia. The study has demonstrated that conventional forest practices on fans have been ineffective for their intended purposes (e.g., safe access) and have exacerbated the impacts of natural hydrogeomorphic processes. To achieve sustainable forest management it is necessary to take a hydrogeomorphic approach when designing drainage structures and locating riparian reserves. Attention must be paid to road design, particularly with roads that climb to stream crossings. The second phase of this project is to develop an operational hazard identification method for forest practices on fans.

\section{Acknowledgements}

Co-operators in the project include Skeena Cellulose Inc. (Terrace), West Fraser Mills Ltd. (Terrace and Smithers), Silvicon Services Inc. (Smithers), Department of Fisheries and Oceans (Smithers), Ministry of Water, Land and Air Protection (Smithers) and Ministry of Forests (Prince Rupert Forest Region). We are indebted to the BC Ministry of Forests, Forest Renewal BC and the University of British Columbia Faculty of Forestry for support in this project. We thank Rita Winkler and an anonymous reviewer for their contributions.

\section{References}

Allen, J.R. 1965. A review of the origin and characteristics of recent alluvial sediments. Sedimentology 5: 89-191.

Alley, N.F. and G.K. Young. 1978. Environmental significance of geomorphic processes in the northern Skeena Mountains and southern Stikine Plateau. BC Min. Env., Res. Analysis Br. Bulletin 3. 83 p. Anon. 1995a. Riparian management area guidebook. Forest Practices Code Guidebook. BC Min. Forests and BC Environment.
Anon. 1995b. Forest Road Engineering Guidebook. Forest Practices Code. BC Min. Forests and BC Environment. 153 p.

Anon. 1999. Mapping and Assessing Terrain Stability Guidebook. Forest Practices Code Guidebook. BC Min. Forests and BC Environment. $36 \mathrm{p}$.

Banner, A., W. MacKenzie, S. Haeussler, S. Thomson, J. Pojar and R. Trowbridge. 1993. A field guide to site identification and interpretation for the Prince Rupert Forest Region. Land Management Handbook 26. BC Min. Forests.

Beaty, C.B. 1970. Age and estimated rate of accumulation of an alluvial fan. White Mountains, California. Amer. J. Sci. 268: 50-77.

Beschta, R.L., R.E. Bilby, G.W. Brown, L.B. Holtby and T.D. Hofstra. 1987. Stream temperature and aquatic habitat: fisheries and forestry interactions. In E.O. Salo and T.W. Cundy (eds.). Streamside Management: Forestry and Fishery Interactions. pp. 191-232. U. of Wash. Institute of Forest Resources.

Bisson, P.A., R.E. Bilby, M.D. Bryant, C.A. Dolloff, G.B. Grette, R.A. House, M.L. Murphy, K.V. Koski, and J.R. Sedell. 1987. Large woody debris in forested streams in the Pacific northwest: past, present, and future. In E.O. Salo and T.W. Cundy. (eds.). Streamside Management: Forestry and Fishery Interactions. pp. 143-190. U. of Wash. Institute of Forest Resources.

Bjornn, T.C. and D.W. Reiser. 1991. Habitat requirements of salmonids in streams. In W.R. Meehan (ed.). Influences of forest and rangeland management on salmonid fishes and their habitats. pp. 83-138. Amer. Fish. Soc. Special Pub. 19.

Bull, W.B. 1977. The alluvial-fan environment. Progress in Physical Geography. v.1: 222-270.

Church, M. and J.M. Ryder. 1972. Paraglacial sedimentation: A consideration of fluvial processes conditioned by glaciation. Geol. Soc. Amer. Bull. 83: 3059-3072.

Clague, J.J. 1984. Quaternary geology and geomorphology, SmithersTerrace-Prince Rupert area, British Columbia. Geol. Survey of Can. Memoir 413. $71 \mathrm{p}$

Costa, J.E. 1984. Physical geomorphology of debris flows. In J.E. Costa and J.P. Fleisher (eds.). Developments and applications of geomorphology. pp. 268-317. Springer-Verlag, New York.

Costa, J.E. 1988. Rheologic, geomorphic, and sedimentologic differentiation of water floods, hyperconcentrated flows, and debris flows. In V.R. Baker, R.C. Kochel and P.C. Patton (eds.). Flood Geomorphology. pp. 113-122. John Wiley, New York.

Holland, S.S. 1964. Landforms of British Columbia, A Physiographic Outline. Bulletin No. 48. BC Dept. of Mines and Petroleum Resources. $138 \mathrm{p}$.

Innes, J.L. 1985. Magnitude-frequency relations of debris flows in northwest Europe. Geograf. Ann. 67 A: 23-32.

Jakob, M. and P. Jordan. 2001. Design flood estimates in mountain streams - the need for a geomorphic approach. Can. J. Civ. Eng. 28: 425-239. Johnston, N.T. and P.A. Slaney. 1996. Fish habitat assessment procedures. BC Min. Env., Lands and Parks, and BC Min. For. Watershed Restoration Tech. Circular 8.97 p.

Kellerhals, R. and M. Church. 1990. Hazard management on fans, with examples from British Columbia. In A.H. Rachochi and M. Church (eds.). Alluvial fans: a field approach. pp. 335-354. John Wiley and Sons, New York.

Mah, S., S. Thomson and D. Demarchi. 1996. An ecological framework for resource management in British Columbia. Environmental Monitoring and Assessment 39: 119-125.

Murphy, W.L. and W.R. Meehan. 1991. Stream Ecosystems. In W.R. Meehan (ed.). Influences of forest and rangeland management on salmonid fishes and their habitats. pp. 17-46. Amer. Fish. Soc. Special Pub. 19.

Pierson, T.C. and J.E. Costa. 1987. A rheologic classification of subaerial sediment-water flows. In J.E. Costa and G.F. Wieczorek (eds.). Debris flows/avalanches: process, recognition, and mitigation. pp. 1-12. Geol. Soc. Amer. Reviews in Engineering Geology. Vol. VII. 
Ritter, J.B., J.R. Miller, Y. Enzel, S.D. Howes, G. Nadon, M.D. Grubb, K.A. Hoover, T. Olsen, S.L. Reneau, D. Sack, C.L. Summa, I. Taylor, K.C.N. Touysinhthiphonexay, E.G. Yodis, N.P. Schneider, D.F. Ritter and S.G. Wells. 1993. Quaternary evolution of Cedar Creek alluvial fan, Montana. Geomorphology. 8: 287-304. Runka, G.G. 1972. Soil resources of the Smithers-Hazelton area. BC Dept. Agr., Soil Survey Division. Kelowna. BC. 234 p.

Ryder, J.M. 1971a. The stratigraphy and morphology of paraglacial alluvial fans in south-central British Columbia. Can. J. Earth Sci. 8: 279-98.

Ryder, J.M. 1971b. Some aspects of the morphometry of paraglacial alluvial fans in south-central British Columbia. Can. J. Earth Sci. 8 1252-1264.

Septer, D. and J.W. Schwab. 1995. Rainstorm and flood damage: northwest British Columbia 1891-1991. BC Min. For. Land Man. Handbook $31.196 \mathrm{p}$.
Smith, G.A. 1986. Coarse-grained nonmarine volcaniclastic sediment: terminology and depositional process. Geol. Soc. Amer. Bulletin. 97: 1-10.

Thurber Consultants. 1983. Debris Torrent and Flooding hazards, Highway 99, Howe Sound. Report to the BC Min. Trans. and Highways. 25 p.

VanDine, D.F. 1985. Debris flows and debris torrents in the southern Canadian Cordillera. Can. Geotechnical J. 22: 44-68.

Wells, S.G. and A.M. Harvey. 1987. Sedimentologic and geomorphic variations in storm-generated alluvial fans, Howgill Fells, northwest England. Geol. Soc. Amer. Bulletin. 98: 182-198.

Wilford, D.J., M.E. Sakals and J.L. Innes. 2002a. Forest Management and Restoration on Fans. Watershed Restoration Tech. Bulletin Streamline. 6(3): 1-8. 